ERC Working Papers in Economics 07/01 January 2007

\title{
Brain Drain from Turkey: An Investigation of Students' Return Intentions
}

\author{
Nil Demet Güngör \\ Economics Department, Atılım University, Ankara 06836 Turkey \\ Phone: + 903125868605 \\ Fax: +90 3125868091 \\ e-mail: ndgungor@atilim.edu.tr \\ Aysit Tansel \\ Department of Economics \\ Middle East Technical University \\ Ankara 06531 Turkey \\ e-mail: atansel@metu.edu.tr
}




\title{
Brain Drain from Turkey: An Investigation of Students' Return Intentions ${ }^{1}$
}

\author{
Nil Demet Güngör \\ Economics Department, Atılım University, Ankara 06836 Turkey \\ Phone: + 903125868605 \\ Fax: +90 3125868091 \\ E-mail: ndgungor@atilim.edu.tr
}

\author{
Aysit Tansel ${ }^{2}$ \\ Economics Department, Middle East Technical University, Ankara 06531 Turkey \\ and \\ Institute for the Study of Labor (IZA), Bonn, Germany \\ Phone: +90 3122102057 \\ Fax: +903122107964 \\ E-mail: atansel@metu.edu.tr
}

\begin{abstract}
The emigration of skilled individuals from Turkey attracted greater media attention and the interest of policymakers in Turkey, particularly after the experience of recurrent economic crises that have led to an increase in unemployment among the highly educated young. This study estimates a model of return intentions using a dataset compiled from an Internet survey of Turkish students residing abroad. The findings of this study indicate that, as expected, higher salaries offered in the host country and lifestyle preferences, including a more organized environment in the host country, increase the probability of student non-return. However, the analysis also points to the importance of prior return intentions and the role of the family in the decision to return to Turkey or stay overseas. It is also found that the compulsory service requirement attached to government scholarships increases the probability of student return. Turkish Student Association membership also increases return intentions. Longer stay durations, on the other hand, decrease the probability of return. These findings have important policy implications.
\end{abstract}

Keywords: Student non-return, brain drain, return intentions, Turkey JEL Codes: F20, F22

\footnotetext{
1 This study is based in part on the $\mathrm{PhD}$ thesis of Nil Demet Güngör, supervised by Aysit Tansel in the Economics Department of Middle East Technical University (Güngör, 2003). Support of the Turkish Academy of Sciences Fellowship Program for doctoral studies and the financial support of the METU Research Fund, coded AFP-2000-4-03-06 are gratefully acknowledged. The authors would like to thank Cem Somel for providing insightful discussions on this topic. In addition, we thank branch manager Ayfer Çakıroğlu of the Statistics and Coordination Division of the Ministry of Education General Directorate of Higher Education for her help in interpreting the Ministry's data on students abroad.

${ }^{2}$ Corresponding author.
} 


\section{Brain Drain from Turkey: An Investigation of Students' Return Intentions}

\section{INTRODUCTION}

The migration of highly educated individuals is often considered to be an expensive "gift" given by the developing world to the economically advanced countries, where the developed countries reap the benefits of developing countries' investments in education at apparently little cost. In the human capital approach to migration, the expected wage differential between the host and source countries is cast as the key determinant of skilled migration. Expected wage levels are tied not only to the prevailing incomes in various occupations, but also to the job opportunities that exist within professions. In addition, the individual migration decision is believed to be motivated by a number of "pull" factors, such as favorable compensation packages, a world-class work environment, better living conditions, active recruitment by employers, and in part by "push" factors that originate in the home country that may include political instability, cost of living/inflation, and the inability to find work. The paper focuses on the Turkish brain drain and presents an empirical investigation of the return intentions of Turkish students that relies on questionnaire data collected from an internet survey ${ }^{3}$.

In the 1960s, many doctors and engineers left Turkey to work in the West, most of them choosing to settle in Europe. They were among the first highly skilled émigrés from Turkey. In more recent periods, a slightly different phenomenon has come to be recognized as an

\footnotetext{
${ }^{3}$ Other micro level empirical studies of the brain drain include studies on the Asian engineering brain drain (Niland, 1970), studies on China (Kao and Lee, 1973; Zweig and Changgui, 1995), and on Latin America (Cortés, 1980). Studies focusing on the Turkish brain drain include Oğuzkan (1971, 1975) and Kurtuluş (1999). Oğuzkan's studies are based on a survey conducted in 1969 of 150 respondents holding a doctorate degree and working abroad, while the study by Kurtuluş looks at the responses of 90 students studying in the United States in 1991.
} 
important source of brain drain: the non-return of students studying abroad leading to emigration of professionals in all fields. While it is generally difficult to obtain complete, consistent, let alone accurate, figures for skilled emigration, it is generally believed that brain drain is increasingly becoming an important issue for Turkey. Informal evidence indicates that there are more individuals with higher education emigrating from Turkey today than there were 30 years ago. This is not surprising given that education levels in Turkey have increased over time. There are, however, few formal statistics available to show whether the proportion of skilled emigrants out of the tertiary educated population has increased. A study undertaken by the Statistical Office of the European Communities, which involved interviews with 1564 households in Turkey, nevertheless seems to corroborate the view that migrants from Turkey are generally more educated than non-migrants (EUROSTAT, 2000). As well, a significant proportion (about 40 percent) of Turkish immigrants who migrated to the US in the 1990s hold a tertiary level degree, which is more than twice the tertiary school enrollment ratio in Turkey (Özden, 2005: 235).

In fact, there are many indications of significant human capital transfer out of Turkey. Turkey is a middle income country that ranks $24^{\text {th }}$ among countries sending skilled workers abroad according to UN sources. Turkey is also among the top ten in terms of the number of students studying in US higher education institutions, along with much more populous countries such as India and China. In the 2004-2005 academic year, the number of Turkish students in the US grew by 9 percent to 12,474 , which was the highest rate of increase among the top sending countries (Institute for International Education, 2005). Official Ministry of Education figures indicate that, as of 27 February 2006, the number of students studying abroad at the undergraduate and graduate levels was around 21,400, with about a thousand of these students being sponsored by various governmental sources (Ministry of Education of 
Turkey, 2006). UNESCO statistics, however, suggest that this figure is significantly higher ${ }^{4}$. Approximately 52,000 Turkish students studied abroad in 2004, mainly in Germany, USA, France and England, making Turkey the $7^{\text {th }}$ highest ranking country in terms of gross outflow of students (UNESCO, 2006).

While an increasing number of educated individuals from Turkey are choosing to study and work abroad, Turkey's ranking in education levels has remained constant. Turkey continues to lag behind skilled immigrant receiving countries in educational attainment levels and educational resources including number of teachers and schools, although there have been improvements over time. The educational attainment of the labour force more than doubled between 1970 and 2000, increasing from 2.8 to 6.5 years. During this period, male educational attainment rose from 3.6 to 7.1 years, and female educational attainment rose from 2.8 to 5.4 years (Tansel and Güngör, 1997; Statistical Institute of Turkey, 2000). In 1997, the compulsory level of schooling was raised from five to eight years. Gross enrollment rates at the compulsory education level increased from 92.0 percent in 1997 to 100.5 percent in 2004 for males. For females the increase was from 79 percent to 95.7 percent for the same period. There were also improvements in gross enrollments at the secondary and tertiary levels of education. The gross secondary schooling enrollment ratio increased from 46 percent to 96 percent for males, and from 30 percent to 71 percent for females in the period between 1990 and 2004. At the tertiary level, the gross enrollment ratio increased from 16.4 percent to 27.5 percent for males, and from 8.7 percent to 20.5 percent for females during the same period (Statistical Institute of Turkey, 2004). These developments have placed a strain on the

\footnotetext{
${ }^{4}$ The reason for the disparity between Ministry of Education and UNESCO figures is that the former only include students who have officially informed the Ministry of their intention to study abroad. There are many students who go abroad with their own means who do not notify the Ministry. In general, those who notify the Ministry do so in order to be exempted from the exit tax when leaving Turkey or to delay their military service in the case of males.
} 
resources of Turkey's higher education system, and study opportunities abroad have helped to relieve some of the pressure on universities in Turkey.

Despite the fact that enrollments are rising and Turkey's labour force is becoming more educated, there remains a persistent gender gap as well as a gap with the education levels of the developed world as evident in the mean years of schooling data provided in Barro and Lee (2000). The difference in the average schooling level between Turkey and the United States, for example, has remained at seven years in the period between 1960 and 1999. The continuing disparities in education increase uncertainties about Turkey's ability to catch up to the development level of the advanced economies without active national strategies to keep and use skilled workers effectively.

The media and policymakers in Turkey have turned greater attention to the loss of Turkey's educated workforce in the aftermath of the economic crises in November 2000 and February 2001, where a third of the educated workforce became unemployed (Işığıçok, 2002). Economic uncertainty is believed to have hastened the emigration of skilled individuals from Turkey, since many university graduates who are unable to find jobs in Turkey look for ways to go abroad to study or to work and many students studying abroad postpone their return if they do not have jobs waiting for them. The loss of skilled individuals through brain drain or student non-return is therefore an important issue that Turkey's policymakers must confront ${ }^{5}$.

The purpose of the paper is to present an empirical investigation of the determinants of return intentions of Turkish students studying abroad. It is based on data collected from an internet survey conducted by the authors during the first half of 2002 that resulted in over 1000 responses $^{6}$. The information collected this survey is used to determine the empirical importance of various factors on the return intentions of Turkish students. The findings of this

\footnotetext{
${ }^{5}$ There is a renewed interest in the study of the brain drain phenomenon as is evidenced by the publication of a recent book by Özden and Schiff (2005) as well as recent articles surveyed in Commander et al. (2004).

${ }^{6}$ For a detailed analysis of the characteristics of the survey respondents see Tansel and Güngör (2003).
} 
study indicate that, as expected, higher salaries offered in the host country and lifestyle preferences, including a more organized environment in the host country, increase the probability of student non-return. However, the analysis also points to the importance of prior return intentions and the role of the family in the decision to return to Turkey or stay overseas. Those who initially intended to return are more likely to indicate a current intention of return and vice versa. Further, greater family support for returning results in greater probability of having return intentions. It is also found that the compulsory service requirement attached to government scholarships increases the probability of having return intentions, while an increase in the length of stay increases the probability of having non-return intentions. Membership in Turkish Student Association is a factor that increases return intentions. These findings have important policy implications.

Following the introductory section, Section II presents a brief discussion of the survey methodology and provides details of the model selection and estimation procedures. The empirical specification of the model and the explanatory variables used are given in Section III. This is followed by a discussion of the estimation results of the factors determining the return intentions of Turkish students in Section IV and Section V. Section VI presents the conclusions.

\section{METHODOLOGY}

The results of the current study are based on data from an internet survey collected by the authors during the first half of 2002. The survey methodology is described in detail in Appendix A.1. In the econometric analysis of return intentions described in this section, we set out to determine the factors that are significant in explaining the return intentions of students. The dependent variable is the likelihood of returning to Turkey based on the response to the question "What are your current intentions about returning to Turkey?". The table below shows the possibilities presented to respondents. 


\begin{tabular}{lc}
\hline Response Categories & Index \\
\hline Students & \\
I will return as soon as possible without completing my studies. & 1 \\
I will return immediately after completing my studies. & 2 \\
I will definitely return but not soon after completing my studies. & 3 \\
I will probably return. & 4 \\
I don't think that I will be returning. & 5 \\
I will definitely not return. & 6
\end{tabular}

These choices form a set of ordered categories in which each consecutive category indicates an increase in intensity in the respondents' intentions to stay in their current country of residence. Because of the way the index is constructed, categories with a higher index value indicate stronger feelings about not returning (staying). This means that positive coefficients on the independent variables imply an increase in the probability of having nonreturn intentions, while negative coefficients imply an increase in the probability of having return intentions.

However, the change in intensity between categories cannot be assumed to be uniform. Given the ordered and non-uniform nature of these choices, the appropriate model is an ordered response model (Maddala, 1983). Formally, the observed discrete index is given by

$$
y_{i}=\{1,2,3, \ldots, J\}
$$

where $i$ indexes the observations and $J$ is the number of categories of the dependent variable. It is assumed that a continuous, latent variable underlies the discrete, ordered categories. This latent variable is explained by a set of observed characteristics and a random element as given below:

$$
y_{i}^{*}=\beta X_{i}+u_{i}
$$

where $y^{*}$ is the unobserved "return intention" variable, $X$ is the $(k \times 1)$ vector of explanatory variables, $\beta$ is the parameter vector to be estimated and $u$ is the random disturbance term. The 
relationship between the discrete, observed $y$ and unobserved, continuous $y^{*}$ is given as follows:

$$
y_{i}=\left\{\begin{array}{l}
1 \text { if } y_{i}^{*} \leq 0\left(=\mu_{1}\right) \\
2 \text { if } 0<y_{i}^{*} \leq \mu_{2} \\
3 \text { if } \mu_{2}<y_{i}^{*} \leq \mu_{3} \\
4 \text { if } \mu_{3}<y_{i}^{*} \leq \mu_{4} \\
\cdots \\
J \text { if } \mu_{J-1} \leq y_{i}^{*}
\end{array}\right.
$$

where $\mu_{1}, \mu_{2}, \mu_{3} \ldots \mu_{J-1}$ are the threshold parameters linking $y$ to $y^{*}$ that are estimated along with the explanatory variable coefficients. The ordered probit specification, which assumes an underlying normal distribution for the error term, is used in this study to estimate the model of return intentions. Given an ordered probit specification, the probability that an observed response falls into an arbitrary category $j$ is given below as:

$$
\operatorname{Prob}\left(y_{i}=j\right)=\Phi\left(\mu_{j}-\beta^{\prime} x_{i}\right)-\Phi\left(\mu_{j-1}-\beta^{\prime} x_{i}\right)
$$

where $\Phi($.$) is the cumulative normal distribution. Differentiating this probability with respect$ to the explanatory variables gives the marginal effect of each on the probability of choosing category $j$. Model estimation is carried out by using maximum likelihood (ML) estimation techniques since it has been shown that ML gives unbiased and efficient estimates for nonlinear models. Further details of the choice of estimation methodology are presented in Appendix A.2.

\section{EMPIRICAL SPECIFICATION OF THE MODEL}

We estimate an ordered probit model of return intentions of Turkish students where the dependent variable is the return intentions explained in the previous section with the specified six categories taking on values 1 through 6 . Human capital theory emphasizes the role of income disparities in migration decisions (Sjaastad, 1962). A wage differential existing between the country of origin and the country of destination is seen as the primary 
determinant of migration flows. Various push and pull factors are also discussed in the migration literature to explain the emigration of skilled individuals. Push factors are those characteristics emanating from the environment of the home country that prompt individuals to migrate abroad. They include various economic, institutional, professional and political factors, including unsatisfactory income levels, inadequate work conditions, lack of career development opportunities as well as economic and political uncertainty. Pull factors, on the other hand, are opportunities provided by the host country such as better pay, greater learning and professional development prospects that attract students and professionals to the host country.

To explain the return intentions of Turkish students, we use a set of variables that are suggested by human capital theory as well as variables that are considered to be relevant in the Turkish case in the empirical estimation. They include various "subjective" variables that are used to determine the significance of a range of economic, social, political and human capital factors. Some are based on the respondents' rankings of various push and pull factors in terms of their importance in their intention to return or stay ${ }^{7}$. The final empirical model is chosen on the basis of goodness-of-fit statistics: mainly the AIC and McFadden's adjusted $\mathrm{R}^{2}$. The likelihood ratio test was also used in comparing nested models. In general, these three statistics gave very similar results. A total of 48 regressors form the final estimation model, many of which are qualitative or dummy variables, as well as interaction variables. The details of the model selection process are supplied in Appendix A.3. The next section discusses the rationale for considering each of the variables and their empirical importance in determining the return intentions of Turkish students.

\footnotetext{
${ }^{7}$ The push-pull factors considered in the study are constructed as dummy variables taking on the value "one" if they scored high on a 5-point Likert scale (e.g., received either a score of "five" or a "four" as an important factor) and a value of "zero" if they were relatively unimportant in determining return intentions (e.g., received a score of "three" or less).
} 


\section{IV.ESTIMATION RESULTS OF THE ORDERED PROBIT MODEL OF RETURN INTENTIONS}

Table 1 provides descriptions, summary statistics and estimation results for the variables used in the ordered probit model of return intentions. Estimates of the marginal effects of selected variables from the final estimation model are provided in Table 2. The marginal effects are calculated as the change in the probability of choosing a particular return intention category for the selected explanatory variables. All empirical work was done using STATA and the standard errors of the marginal effects of variables with interactions were obtained using the program called Clarify developed by Tomz, Wittenberg and King (2001). Standard errors of the change in probabilities are given in parentheses below the marginal effects. The categories of the return intentions variable $(y)$ are labeled from 1 to 6 , with one corresponding to the highest return intention category and six corresponding to the lowest return intention category. Negative values for the marginal effects indicate that the probability of choosing a certain return intention category falls while positive values indicate that this probability rises. If the respondent is female, for example, the probability that she will indicate that she definitely does not intend to return to Turkey (which is the probability of choosing category six) is 0.0008 greater than the same probability for males (see Table 2 ). The interpretation is similar for the other categories of the current return intentions variable. Below we provide a discussion of the variables considered in determining the return intentions of students.

Gender Effects $\left(\boldsymbol{X}_{1}\right)$ : The dummy variable for gender takes on the value 1 for "female" and 0 for "male". In previous empirical studies, women have been found to be more reticent about returning to their homelands. In the case of China (Zweig and Changgui, 1995: 36-7), for example, this is believed to be caused by a lack of career opportunities for women (e.g., the biases they face in the workplace) and constraints imposed on their behavior in China, as 
well as certain convenience factors abroad, aside from greater wage levels, that offer them a more comfortable lifestyle than they could expect to experience in China. These factors, including less lifestyle freedom, may also be important for women in Turkey making them less willing to return. The positive coefficient estimate for gender (see Table 1) means that females are less likely to indicate that they will be returning to Turkey compared to males. This is similar to the findings for Chinese women. However, gender is not statistically significant in the final preferred model presented in Table 1 , although it was initially positive and statistically significant in the simpler models with few explanatory variables (not presented).

Age Effects $\left(X_{2}, X_{3}\right)$ : "Age" and "Age squared" are included as explanatory variables in order to control for cohort effects and possible nonlinearities. Previous empirical research has established age as an important factor in determining the net present value of migration. Controlling for the effect of stay duration, age is expected to have a negative effect on the probability of migration (Goss and Paul, 1986). According to Chen and Su (1995), older students may be expected to exhibit stronger return intentions than younger students who face a longer time frame for working and earning a high salary level in the foreign country. In the final preferred model presented in Table 1, age has a positive coefficient and the square of age has a negative coefficient, indicating that the probability of having weak return intentions increases with the age of the participant at a decreasing rate. This result seems to counter the intuition provided by Chen and $\mathrm{Su}$, although it is not an implausible result: older students may find it more difficult to return because returning to Turkey (going through a reverse migration process) may involve greater psychic costs. These two variables, however, are not statistically significant in explaining differences in return intentions for the overseas Turkish student population, although in the initial model explorations of simple specifications (not presented) the age variables were significant. 
Stay Duration $\left(\boldsymbol{X}_{\boldsymbol{6}}\right)$ : Stay duration is the number of years spent in the host country. When stay duration increases, the incentive to return is expected to diminish, since individuals become more accustomed to living abroad. Thus, there may be an "inertial effect" with an increase in the length of stay. Longer stay duration may also be indicative of a preference to live abroad, whether existing initially or acquired with time. Since the stay duration variable also incorporates the effects of age, initial preferences and work experience, controlling for these variables will reveal the "pure inertial effects" of stay duration. To our knowledge, the empirical importance of stay duration is not previously investigated in the brain drain literature. However, in a study of guest workers in Germany, Waldorf (1995) found that the probability of indicating return intentions declines with the length of stay.

In Table 1 , the stay duration variable is positive and statistically significant at the 1 percent significance level indicating that as the length of stay in the host country increases, the tendency to stay abroad also increases. The marginal effects of different stay durations for each return intention category are given in Figure 1. Two important observations appear from this figure. One is that the probability of having strong return intentions declines with the length of stay in the host country. The other important observation is that the probability of indicating strong non-return intentions increases with the stay duration abroad. These observations are as expected since the passage of time may help to overcome adjustment problems of respondents if they exist. Stay duration may also lead to a weakening of ties to Turkey, and a strengthening of ties to the country of study.

According to one survey participant, finding a job in Turkey is dependent on informal networks and the longer one stays abroad the greater is their exclusion from these networks. Others have indicated that re-adapting to Turkey can be as difficult as the initial adjustment to a foreign culture when stay duration increases, since they believe social change occurs "much faster in Turkey". So, while the length of stay increases familiarity with the host country it 
may also increase the psychological distance with the social and work environment of the home country.

Initial Return Intentions $\left(\boldsymbol{X}_{4}, \boldsymbol{X}_{5}\right)$ : In a study of Asian engineering brain drain to the United States by Niland (1970), it has been shown that a majority of the Indian and Chinese engineering students surveyed had made initial plans to remain abroad, indicating that "the seeds of drain ... had germinated even prior to the departure from the home shores." In Zweig and Changgui's (1995) study on the Chinese brain drain, previous intentions about returning also held significant predictive power over current return intentions for Chinese scholars and students residing in the United States. Prior conditioning about circumstances abroad relative to those of the home country may lead individuals in the less developed countries to view study or work abroad as an escape route to better circumstances, especially if the undesirable conditions in the home country are believed to be chronic. Anecdotal evidence also tends to confirm this observation for the case of Turkey.

In the current study, we formally test the empirical significance of prior return intentions. Respondents were asked about their initial return intentions prior to going abroad to work or study. The possible responses were "return", "undecided" and "stay". A little more than half of the students sampled intended to return prior to leaving Turkey, while one out of every ten students intended not to return and the remainder was unsure about returning. Two dummy variables, $X_{4}$ for "unsure" and $X_{5}$ for "return", are included in the model to determine whether differences in the initial intention of the respondent prior to his/her venture abroad is important in determining his/her current intentions about returning to Turkey. "Stay" is chosen as the reference category. It is expected that respondents who left Turkey with the intention to return will be more likely to express the same intention at the time of filling out the survey. 
The coefficients of the variables representing initial return intentions are positive and statistically significant at the 1 percent significance level (see Table 1). These results indicate that those who have initially indicated that they will "stay" in the current country or are "unsure" about returning are more likely to indicate that their current intention is to "not return". The probability of not returning $(y=5,6)$ decreases by 0.32 when initial intention changes from "stay" to "unsure" and by 0.38 when the initial intention changes from "stay" to "return" (computed from Table 2). These large marginal effects suggest that initial views before going abroad are important in shaping the current intentions of Turkish students studying abroad.

Family Support $\left(X_{7}, X_{8}\right)$ : Family considerations, such as family attitudes and support relating to the migration decision, are expected to have a significant impact on the return decision of respondents. Several studies, such as Zweig and Changgui (1995) for China and Niland (1970) for Asian engineering students, confirm the importance of the family in an individual's mobility decision, although the results of Niland's study are not uniform across the five countries studied. In this study, students were asked the degree that they felt that their families supported them in the initial decision to study abroad and whether they would support them in the decision to settle abroad permanently. For the initial decision to study abroad, three-quarters of the student sample indicated that their families were very supportive. In comparison, family encouragement to settle abroad was considerably less, although still high (53 percent of the sample).

The family support variables are ordinal categorical variables that are treated as interval variables in the econometric model ${ }^{8}$. Family support for the initial decision to go abroad is not statistically significant in determining current intentions on returning. On the other hand, greater family encouragement to settle abroad results in a greater tendency to indicate non-

\footnotetext{
${ }^{8}$ The null hypothesis of evenly spaced categories is not rejected by a likelihood ratio test.
} 
return intentions. Compared to respondents whose families are not supportive, the likelihood of not returning ( $y=5$ or 6$)$ increases by 0.04 for those whose families are somewhat supportive, and by 0.08 for those whose families are definitely supportive ${ }^{9}$ (see Table 2). These estimates indicate that family support is another important determinant of return intentions. Greater family support for settling abroad results in greater probability of not returning. When the respondent's family is not supportive of the decision to settle abroad, the probability of return intentions are higher.

Marriage to a Foreign Spouse $\left(\boldsymbol{X}_{14}\right)$ : The marital status of respondents is considered in the model to account for the existence of family constraints. Respondents who are not married are freer in their mobility choice, while married respondents must also consider the effect of their mobility decision on their families. Marriage to a foreign spouse is expected to reduce return intentions, while marriage to a Turkish spouse may either reduce or increase return intentions depending on the spouse's preferences and position in the family. About a quarter of the students surveyed are married. However, the most significant impact on return intentions occurs for those who are married to a foreign spouse, which accounts for only about 1 percent of those surveyed. The estimated marginal effects in Table 2 indicate that marriage to a foreign spouse reduces the probability of returning after completing studies. Not

\footnotetext{
${ }^{9}$ Initially, dummy variables for each category were included in the model as explanatory variables. Since the first three categories "actively discourage", "not very supportive" and "not sure" are not statistically different from each other, they are combined into the broader category of "not supportive", which is used as the reference category. The same is done for the "somewhat supportive" and "most likely supportive" categories since they are also not statistically different from each other. They are combined into a new "somewhat supportive" category. Only the "definitely support" category is kept unchanged. In Table 1, the signs on the "somewhat supportive" and "definitely support" dummy variables are positive and statistically significant at the 5 percent and 1 percent significance level respectively indicating that family support for settling abroad weakens return intentions.
} 
surprisingly, this has the highest marginal impact on non-return: the probability of definitely not returning or return being unlikely ( $y=5$ or 6 ) increases by 0.15 (computed from Table 2 ).

Effects of Parents' Education: Access to overseas study opportunities tends to favor students with more privileged circumstances and greater financial means. Chinese scholars and students interviewed by Zweig and Changgui (1995), for example, came from high socioeconomic backgrounds. More than half were the children of intellectuals and an important proportion of them came from the "middle level cadres", which suggested "unequal access to channels out of China”. Such unequal access also appears to be true in the Turkish case. The respondents who took part in our survey have highly educated families relative to average education levels for Turkey. Female students, in general, have more educated parents than male students: three-quarters of female students and two-thirds of male students have fathers who possess a bachelor's or higher level degree. While half of all mothers of female students hold a tertiary level degree, the same is true for only two-fifths of the mothers of male students (Tansel and Güngör, 2003).

While there was no a priori expectation about the direction or impact of parental education on return intentions, mother's and father's educational levels were nevertheless included in initial models as possible socioeconomic background indicators for the respondents. A dummy variable was constructed for each level of education and different levels of education were used as reference to determine whether any significant differences existed in the return intentions of students with different family backgrounds. Since parental education effects on return intentions were not statistically significant in any of the model specifications, they were excluded from the final preferred model. We conclude that socioeconomic background appears to have greater importance in determining who can take advantage of study opportunities abroad than in determining students' return intentions once abroad. 
Academic Conditions: Students were asked to compare their academic environments in their current country of study to that in Turkey. The great majority (close to 90 percent) of students indicated that academic conditions were either "better" or "much better". A dummy variable was constructed for each assessment category, and only the "much worse" category appeared statistically significant at the 5 percent significance level with reference to the other categories in the initial simpler models. However, only two individuals chose the "much worse" category, and when this category was chosen as the reference, none of the other categories were statistically significant. This indicates that the academic assessment variables do not have any explanatory power on return intentions and are excluded from the final preferred model.

Language Facility / Skill: Studies, such as those of Benarroch and Grant (2004) and Finnie (2004), which deal with the determinants of inter-provincial migration in Canada, have shown that language differences can act as a significant barrier in the decision to migrate to a new location. Quebec, the sole French-speaking province, had considerably less in- and outmigration compared to the English-speaking provinces for the periods considered in the two studies. For many international migrants, language skills are an important part of adjusting to life abroad. The greater the command of a foreign language, the easier it is to make the transition to a different culture. Language acquisition is also related to the age of the respondent, which suggests that those who go abroad at an earlier age will have an advantage in learning a new language. In addition, early exposure to foreign language instruction in the home country is expected to improve language skills and prepare students for foreign study or work experience. Studies such as Gazioğlu (1996) and Chiswick (1995), for example, have found language proficiency to be important in determining the labour market earnings of immigrants. 
Dummy variables for the language of instruction in high school science and social science classes were included initially to account for the effect of early exposure to a foreign language, with the expectation that those who have received foreign language instruction early on (about 60 percent of the sample) will exhibit weaker return intentions than those who have completed their high school education in Turkish language schools. However, the effect of early exposure to a foreign language at the high school level on return intentions was found to be statistically insignificant and therefore excluded from the final model. This result is probably due to the fact that a great majority of respondents in our sample are graduates of foreign language instruction universities, such as Middle East Technical University, Bilkent University and Boğaziçi University (Tansel and Güngör, 2003). In addition, 82 percent of the respondents at the undergraduate study level are graduates of foreign language instruction high schools. It is reasonable to suggest, therefore, that study abroad and skilled migration tends to be a selective process that is facilitated by prior knowledge of a foreign language. However, foreign language instruction at the high school level is found to be insignificant in determining return intentions.

Social Life Abroad ( $\left.X_{9}\right)$ : The social environment is expected to be important in explaining differences in return intentions of students. A third of respondents have indicated that their current social environment is "neither better nor worse" than it was in Turkey, and a significant number (43 percent) indicate that it is "worse" or "much worse". The above categories above were reduced to three (not counting the "don't know" category) by combining the "worse" and "much worse" categories, and the "better" and "much better" categories. With "much worse" as the reference category, both the "neither better nor worse" and "better" categories are positive and statistically significant at the 1 percent significance level. When the reference category is "much better", both the "neither better nor worse" and "worse" dummy variables are negative and statistically significant, at the 5 percent and 1 
percent significance levels respectively (see Table 1). These results indicate the importance of the social environment in determining current return intentions. Those who are less satisfied with their social conditions abroad are more likely to indicate that they will return.

Standard of Living Assessment ( $\left.X_{10}\right)$ : Students were also asked to assess their standard of living using the same scale for the social life abroad. The distribution of responses is tilted toward the "much better" end of the scale. Since the coefficients of the "much better" and "better" dummy variables are not statistically different from each other, they are combined. Similarly, the first four categories can also be combined into a single category because they are statistically insignificant with respect to each other. This latter variable is used as the reference. The coefficient of the "standard of living is better" variable is positive and statistically significant at the 5 percent significance level (see Table 1). Not surprisingly, students who assess their standard of living abroad as being better or much better than in Turkey show greater intention to not return.

Turkish Student Association Membership $\left(X_{11}\right)$ : More than half the students responding to the survey belong to a Turkish student association or society (TSA) at their institution of study. Membership in these cultural associations turns out to be an important determinant of return intentions. The coefficient of the dummy variable for TSA membership is negative and statistically significant at the 1 percent significance level (see Table 1), indicating that students who are members of TSAs are more likely to have stronger return intentions. This may reflect an implied preference on the part of TSA members to be with fellow nationals compared to non-members and is possibly an indication of stronger "cultural ties" to Turkey. If a student is not a member of a TSA, this is because of personal choice or because no TSA exists. Not being a member by choice and not being a member because no TSA exists were not statistically different from each other and were, therefore, used combined as the reference category. 
Fields of Study: Chen and Su (1995) believe that advanced education and on-the-job training abroad are complementary and result in higher productivity and wages if they are received in the same country especially in capital-dependent disciplines, which they determine to be medicine, engineering and business. They argue that these capital-dependent disciplines will suffer more from brain drain than the non-capital dependent disciplines. They attempt to test this empirically with data on Taiwanese students studying in Japan, but fail to find significant differences in the "stay" inclination for students graduating from the capitaldependent disciplines. Kao and Lee (1973) also look at differences in return inclinations among Chinese scholars across disciplines and obtain similar results.

A dummy variable for capital-dependent disciplines was constructed in our analysis to see if the same result would hold for the sample of Turkish students currently studying abroad. This dummy variable turned out to be statistically insignificant ${ }^{10}$. Consequently, we conclude that discipline is not an important determinant of return intentions in our study. This may be because the sample of students is predominantly tilted toward engineering and business; two-fifths of students are studying in the engineering and technical fields, and about a third are in economics or business studies.

Initial Reasons for Going Abroad $\left(X_{15}-X_{23}\right)$ : When a respondent initially goes abroad because education or experience abroad is required by employers in Turkey ${ }^{11}\left(X_{16}\right)$ the

\footnotetext{
${ }^{10}$ A dummy variable for each discipline, in turn, was also used in the model to determine whether certain fields of study are more prone to brain drain than other. The disciplines are "architecture", "economic and administrative sciences", "engineering and technical sciences", "education sciences", "language and literature", "math and natural science", "medicine", "social sciences", and "arts". None were found to be statistically significant from each other except for education sciences at the 5 percent significance level in the initial, simpler models.

${ }^{11}$ For example, Middle East Technical University requires education or experience abroad before granting tenure track academic positions.
} 
probability of returning immediately increases by 0.03 (see Table 2). This is one of the important "push" factors that cause many who are contemplating academic careers in Turkey to go abroad. While the probability of return increases when respondents have left because of a job requirement, many do not have immediate return plans. Given that stay duration affects the probability of returning negatively, many are not expected to return, especially if they find good positions abroad.

The other reasons for pursuing foreign studies that have a positive effect on return intentions are when respondents go abroad in order to improve their language skills $\left(X_{15}\right)$ or if they want to take advantage of the prestige and opportunities associated with overseas studies $\left(X_{18}\right)$. The positive effect of these two variables on return intentions may be due to the fact that language skills and international degrees are valued in Turkey and the student intends to make an investment toward increasing her/his employability when she/he returns. International diplomas are an important signal to employees in Turkey and many believe that possession of a foreign degree will increase the likelihood of being offered a job or being promoted. Therefore, if the reason for pursuing a foreign degree is for its prestige and advantages and in order to develop language skills, it is likely that the student has contemplated study abroad with return in mind, which in turn has a positive effect on return intentions.

When respondents go abroad to get away from the political environment $\left(X_{21}\right)$, or due to lifestyle preferences $\left(X_{19}\right)$, or because they find the facilities and equipment for research to be insufficient in Turkey $\left(X_{17}\right)$, they are very unlikely to return. The probability of not returning $(y=5$ or 6$)$ increases by 0.11 for those who left due to political reasons, by 0.05 for those who left due to lifestyle preferences, and 0.02 for those who left due to insufficient facilities for research (see Table 2). If students choose their current institution of study because of the job opportunities that are provided them $\left(X_{22}\right)$, this increases the probability of not returning 
$(y=5$ or 6$)$ by 0.06 . This is because these students expect to be employed upon completing their studies and thus do not face the uncertainty and psychic costs associated with searching for a job when their studies are completed.

Difficulties Faced Abroad and Adjustment Factors $\left(X_{24}-X_{26}\right)$ : The probability of returning increases when the psychic costs, such as adjustment costs, associated with being in a foreign country are high. Students taking part in the survey were asked whether they faced any difficulties abroad and how they adjusted. Prior overseas experience (work, study or travel) $\left(X_{24}\right)$ before coming to the current country of residence may ease adjusting to or feeling comfortable with the current country of stay and may be expected to delay or postpone return. In addition to previous experience, various other adjustment factors were included in the questionnaire, including having Turkish friends and colleagues in the institution of study $\left(X_{25}\right)$, as well as difficulties such as unfavorable employment prospects in the host country $\left(X_{26}\right)$. These adjustment factors and difficulties faced while abroad are included in the model as dummy variables. Each has a negative coefficient (see Table 1), which indicates an increase the probability of having return intentions.

Although the negative coefficient on previous overseas experience seems counterintuitive, choosing an adjustment factor in the first place is an indication that the respondent did have difficulties in adjusting and had (and possibly still has) higher psychic costs than respondents who did not indicate having any adjustment difficulties. While having Turkish friends at the current institution of study may be important for easing adjustment, those who indicated that this was an important adjustment factor for them are more likely to be returning. This may also be an indication of strong ties to Turkish community and to Turkey for some. As well, when employment prospects abroad are dim $\left(X_{26}\right)$ the probability of returning immediately after completing studies increases by 0.03 . Of these three variables, only previous experience is statistically significant. 
Compulsory Academic Service $\left(X_{28}\right)$ and Plans for Academic Career $\left(X_{27}\right)$ : As expected, students who finance their studies with national scholarships that have a compulsory academic service requirement $\left(X_{28}\right)$ are more likely to be returning immediately after completing their studies. The compulsory service requirement increases the probabilities of return (such as return before completing studies, return immediately after completing studies and return but not soon after completing studies) but reduces the probabilities of nonreturn (such as probable return, return unlikely and definitely not return). The probability of returning immediately is 0.05 for those without a compulsory academic service requirement and 0.17 for those who have this requirement (see Table 2). While the marginal effect between these two groups appears to be large $(0.12)$, what is worrisome is that the probability of returning immediately is not higher. Non-returning students are an indication that the scholarships are not as successful as they can be.

Those who are planning an academic career (e.g., plan to work in academia five years from the survey date) $\left(X_{27}\right)$ are also more likely to have stronger return intentions. The probability of returning immediately after completing studies increases by 0.02 , and the probability of definitely returning but not immediately after completing studies increases by 0.05. Despite the difficulties within the higher education system in Turkey, universities provide greater opportunities for employment compared to other sectors, especially in an environment of economic uncertainty where many university graduates face the prospect of being unemployed.

Income Effects $\left(X_{31}\right)$ : According to human capital theory, the difference in the expected foreign and domestic income levels is a key determinant of skilled migration. To account for the pecuniary aspect of the migration decision, "lack of a satisfactory income level in the home country" was included as a push factor and a "competitive income level in the current country of residence" was included as a pull factor. The approach of using these two 
subjective measures to test the impact of income differences may be justified by the fact that each migrant may have different perceptions of the income differential based on incomplete information of all alternative employment opportunities available to him or her. Not everyone may be equally informed of the prevailing income differentials, and more importantly, they may not place equal weight or importance to the same information. Another difficulty in using actual income differences is that it would require income information for a diverse range of occupations, and comparisons across countries would also need to take into account cost-of-living differences.

Income as a pull factor was statistically significant and thus kept in the final model. As expected, the prospect of a higher level of income abroad $\left(X_{31}\right)$ has a positive coefficient estimate, which means a lower probability of indicating return intentions (see Table 1). Threequarters (76 percent) of those surveyed indicated that income is an important pull factor when deciding whether to return to Turkey. The probability of indicating that return is unlikely is 0.05 higher (see Table 2) for those who indicated that higher income levels abroad is important compared to those who indicated that it is not so central. The importance of salary levels in Turkey for students contemplating an academic career is emphasized in the following comment made by a survey participant.

From talking with students who decide to stay here rather than go back to Turkey, the primary reason is financial. Very able $\mathrm{PhD}$ graduates who can become excellent faculty in Turkey, most of the time decide on even a mediocre job here (which will not satisfy them in the long run) rather than become a faculty member in Turkey with the current salaries. If Turkey does not improve the living standards of university faculty ... the price paid will be incalculable. Here in the US the best go into academia, there it looks like it is the people who either have money or could not find anything else (most of the time). The first thing the country should do is to invest in [the] education of the new generation.

One issue that is raised in this observation is that some of the subjects of the brain drain settle for jobs in the host country that may be below their capacity and education levels. This is one of the concerns discussed by Özden (2005) who indicates that some skilled migration is 
subject to "brain waste". Whether income outweighs other factors such as research facilities and professional opportunities is examined next.

\section{Effects of Additional Push and Pull Factors $\left(X_{29}-X_{38}\right)$ :}

While income differentials appear prominent in migration decisions, it is expected income that is the relevant variable. As such, employment opportunities and labor market conditions both at home and abroad may play an important role in the perceptions of economic opportunity held by skilled individuals. General economic conditions and economic stability will determine relative employment opportunities and can lower or increase an individual's expected income accordingly. Although economic instability or uncertainty is selected as a 'very important' reason by half and an 'important' reason for an additional quarter of respondents (Tansel and Güngör, 2003), it is not statistically significant in determining return intentions. It is therefore not included in the final preferred model.

Two push factors are included in the final ordered probit model of return intentions: being away from research centers / recent advances $\left(X_{29}\right)$ and finding the cultural or social life to be less than satisfying in Turkey $\left(X_{30}\right)$. Being away from research centers and recent advances is positive and statistically significant at the five percent significance level (see Table 1). For those who indicated that this was an important push factor, the probability of return being unlikely $(y=5)$ increases by 0.04 . The impact of this factor on return intentions is even greater for those contemplating academic careers. The interaction term $\left(X_{46}\right)$ is positive and significant, which means that the probability of not returning due to a lack of research facilities and opportunities increases for students who are on an academic track.

The pull factors that significantly affect the return intentions of students are, in order of importance, a higher income level in the host country $\left(X_{31}\right)$ discussed earlier, a more ordered and organized life $\left(X_{34}\right)$, and spouse's preference or job $\left(X_{35}\right)$. The marginal impact of these factors on each return intention category is given in Table 2 . 
Effect of Last Impressions $\left(\boldsymbol{X}_{\mathbf{3 9}}, \boldsymbol{X}_{40}\right)$ : The last impression from the latest trip to Turkey has an important impact on return intentions. The last visit to Turkey changes an individual's perceptions about conditions in Turkey. The probability of returning ( $\mathrm{y}=1$ or 2 ) decreases by about 0.04 for those who were negatively effected by their last trip to Turkey, and increases by 0.05 for those who were left with more positive impressions. These results indicate that perceptions about conditions in Turkey can change with a trip to Turkey, which will then have a positive or negative impact on return intentions depending on the experience of the participant. At the time the survey was conducted, the attacks that took place in New York on September 11, 2001 were relatively new. A dummy variable is included in the model to control for the effect of this incident on return intentions. It takes the value of 1 if the respondent indicates that September 11 increased their return intentions. The coefficient on this variable is positive as expected and the probability of having definite return intentions $(\mathrm{y}=1$ or $\mathrm{y}=2)$ increases by 0.04 .

\section{DISCUSSION}

Table 3 summarizes the effect of various factors considered in determining return and non-return intentions. The two extreme categories at either end of the scale of the return intentions variable are combined together to form the categories "definitely return" and "definitely not return". The highest positive marginal impact on the probability of definitely returning for the sample of students surveyed occurs when the respondent has a compulsory academic service requirement: the probability of returning increases by 0.12 . This is an

important indication that the compulsory academic requirement is an effective means of motivating return. 
Other factors that appear to have great impact on a respondent's probability of definitely returning are family support and having an initial intention to return to Turkey, both of which increase the probability of definitely returning by 0.11 . Having a positive impression from the last visit to Turkey also has a favorable impact on "definitely returning" but to a lesser degree; positive impressions increase the probability of definitely returning by 0.05 . As well, the inability to adapt to the social environment in the host country increases the probability of definitely returning by 0.04 . Perhaps surprisingly, the prospect of unemployment in the host country has a lower marginal effect on return intentions than more fleeting factors, such as the last impression from a visit to Turkey.

The most important factors affecting the probability of definitely not returning are also included in Table 3; they include a combination of economic, political, social and family considerations. Marriage to a foreign spouse has the highest marginal impact $(0.14)$ on the probability of non-return. For students who are married to a foreign spouse (1 percent of those surveyed) this is not surprisingly a very important reason for not returning. Although from the view of policymakers this group may not be an important target in terms of numbers, there is evidence that longer stay durations increases the probability of marriage to a foreign spouse and non-return. A quarter of respondents have indicated that they left Turkey due to political instability, which increases their probability of not returning by 0.11 . Family support for the decision to settle abroad and having a negative impression from the last visit to Turkey also have considerable impact on non-return. They each increase the probability of non-return intentions by about 0.08 . The marginal impact of the income differential is lower: it increases the probability of non-return by 0.05 . Lifestyle factors also have similar marginal effects.

\section{CONCLUDING REMARKS}

The paper investigated the determination and evaluation of various factors that affect the return intentions of Turkish students studying abroad using the results of a survey 
conducted by the authors in 2002. To the extent that the decision to migrate is a well-thought out and planned decision, return intentions will be closely related to the realization of these intentions. However, uncertainty and changing circumstances can easily alter an individual's previous decision. Nevertheless, return intentions can give insights about what is important for individuals when deciding on whether to return or stay.

The empirical investigation of return intentions of Turkish students studying abroad involved the estimation of an ordered probit model based on the human capital theory of migration, which predicts that individuals will migrate when the net present value of benefits from migration is positive. A number of social, economic and political factors turn out be important in discerning between respondents with strong return intentions and those with strong non-return intentions. These include push factors such as political instability and pull factors such as a higher income level abroad and a more ordered and organized life in the host country. Among the pull factors, family considerations, followed by high income levels in the host country and a more ordered lifestyle abroad, in order of importance, all tend to weaken return intentions. Three-quarters of the survey respondents have indicated that higher income levels abroad weigh heavily in their decision to return or stay.

This study also indicates that initial intentions before going abroad are important in shaping current intentions. The probability of having a current intention of not returning is greater when the initial intention of the respondent is to remain abroad. In fact, having an initial return intention to stay abroad has the greatest positive impact on the probability of not returning among the factors considered in the econometric model. On the other hand, those who initially intended to return are more likely to indicate a current intention of return. This positive association between initial and current intentions suggests that intentions may be used as a predictor of future behavior. This link between initial and current return intentions, however, is stronger when the initial intention is to "not return", indicating that non-return is a 
pre-planned decision. Respondents with initial return plans, on the other hand, are more likely to change their previous plans.

The return decision is also determined by the length of stay; the probability of returning decreases as stay duration increases, which suggests that policies to send students abroad should concentrate on giving support for shorter periods of study. The fellowship program for integrated doctoral studies in Turkey and abroad by the Turkish Academy of Sciences is an example of such a policy. While students are expected to complete a major portion of their program requirements in Turkey, they are given financial support to complete part of their studies abroad.

Family support, not surprisingly, has considerable weight in the mobility decisions of the survey participants, indicating that remaining abroad is not simply a matter of earning a higher salary or enjoying better work conditions. Greater family support for returning results in greater probability of having return intentions. Marriage to a foreign spouse is obviously an important factor in not returning, which is more likely as stay duration increases.

Family considerations, lifestyle factors, higher salaries and the political environment appear prominent in determining non-return intentions. On the other hand, compulsory academic service has a positive effect on return intentions, although many of those who intend to return are not planning to return immediately after completing their studies. This may mean that they will eventually decide to stay permanently, since stay duration is shown to have a negative effect on return intentions. Compulsory academic service is an important requirement in the current contracts signed between the student and governmental agencies giving scholarships for study abroad. It is expected that the more stringent the requirements of these scholarships are the greater will be their positive impact on return intentions. So far, these scholarships appear to be an effective means of affecting students' return intentions in the short run, and must be used by the government with due consideration. Another finding is 
that students who are members of Turkish Student Associations are more likely to have return intentions.

Being away from research centers and recent advances in Turkey increases the probability of having non-return intentions especially for students contemplating careers in academia. Long run measures for benefiting from the experience of students with university and postgraduate degrees should include the creation of attractive employment opportunities for using and developing skills in research centers and research related activities in Turkey. Such centers may be supported in various ways by the government.

The findings in this paper suggest that while income levels are important narrowing the wage differential alone will not be sufficient to persuade students to return home. Family considerations and existence of research centers are also important factors in return intentions. Active recruitment policies and successful repatriation programs may increase awareness of opportunities in Turkey. They must be part of a national manpower strategy aimed at creating appropriate employment opportunities for skilled individuals.

\section{References}

Atkinson, R. and Flint, J. (2001) Accessing hidden and hard-to-reach populations: snowball research strategies, Social Research Update, 33, Department of Sociology, University of Surrey, UK (http://www.soc.surrey.ak.uk/sru/SRU33.html).

Barro, R. J. and Lee, J. W. (2000) International data on educational attainment: updates and implications, Harvard University CID Working Paper No. 42, Data Appendix, http://www.cid.harvard.edu/ciddata/ciddata.html.

Benarroch, M. and Grant, H. (2004) The interprovincial migration of Canadian physicians: does income matter?, Applied Economics, 36, 2335-45.

Chen, T.-J. and Su, H.-Y. (1995) On-the-job training as a cause of brain drain, Weltwirtschaftliches Archiv, 131(3), 526-41.

Chiswick, B. R. (1995) The endogeneity between language and earnings: international analyses, Journal of Labor Economics, 13(2), 246-88. 
Commander S., Kangasniemi, M. and Winters, L. A. (2004) The brain drain: curse or boon? A survey of the literature, Chapter 7 in Baldwin, R. E. and Winters, L. A. (eds.) Challenges to Globalization: Analyzing the Economics, Chicago University Press for NBER.

Cortés, C. (ed) (1980) The Latin American Brain Drain to the United States, Arno Press, New York.

EUROSTAT (2000) Push and Pull Factors of International Migration: A Comparative Report, Statistical Office of the European Communities, Luxembourg.

Finnie, R. (2004) Who moves? A logit model analysis of inter-provincial migration in Canada, Applied Economics, 36, 1759-79.

Gazioğlu, Ş. (1996) English language proficiency and the earnings of the Turkish and Bangladeshi immigrants in London, in Ş. Gazioğlu (ed.) Migrants in the European Labour Market, J-Net Publishers, Aberdeen.

Güngör, N. D. (2003) Brain Drain from Turkey: An Empirical Investigation of the Determinants of Skilled Migration and Student Non-Return, unpublished PhD thesis, Institute of Social Sciences, Middle East Technical University, Ankara.

Goss, E. P. and Paul, C. (1986) Age and work experience in the decision to migrate, The Journal of Human Resources, 21(3), 397-405.

Hekmati, M. (1973) Non-returning foreign students: why do they not return home?, Die Dritte Welt, 2(1), 25-43.

Institute for International Education (2005) Open Doors 2005: Report on International Educational Exchange, Institute for International Education, New York.

Işı̆̆ıçok, Ö. (2002) Türkiye'de yaşanan son ekonomik krizlerin sosyo-ekonomik sonuçları: kriz işsizliği ve beyin göçü, (The socioeconomic results of the last two economic crises in Turkey, crisis unemployment and brain drain), www.isguc.org/calhay_beyingocu.php

Kao, C. and Lee, J. W. (1973) An empirical analysis of China's brain drain to the United States, Economic Development and Cultural Change, 21(3), 500-13.

King, G., Tomz, M. and Wittenberg, J. (2000) Making the most of statistical analyses: improving interpretation and presentation, American Journal of Political Science, 44(2), 347-61.

Kurtuluş, B. (1999) Amerika Birleşik Devletleri’ne Türk Beyin Göçü (Turkish Brain Drain to the United States), Alfa Basım Yayım Dağıtım, İstanbul.

Long, J. S. (1997) Regression Models for Categorical and Limited Dependent Variables, Sage Publications, Thousand Oaks, CA.

Long, J. S. and Freese, J. (2001) Regression Models for Categorical Dependent Variables Using Stata, Stata Press, College Station, TX. 
Maddala, G. S. (1983) Limited-Dependent and Qualitative Variables in Econometrics, Econometric Society Monographs, Cambridge University Press, Cambridge.

Ministry of Education of Turkey (2006) Statistics on Students Studying Abroad (http://yogm.meb.gov.tr).

Niland, J. R. (1970) The Asian Engineering Brain Drain: A Study of International Relocation into the United States from India, China, Korea, Thailand and Japan, D. C. Heath and Company, Lexington, Massachusetts.

Oğuzkan, T. (1971) Yurt Dışında Çalışan Doktoralı Türkler: Türkiye'den Başka Ülkelere Yüksek Seviyede Eleman Göçü Üzerinde Bir Araştırma (Turks with Doctorate Degrees Working Abroad: An Investigation of the Migration of Highly Skilled Workers from Turkey to Other Countries), Middle East Technical University, Ankara.

Oğuzkan, T. (1975) The Turkish brain drain: migration of tendencies among doctoral level manpower, in R. E. Krane (ed.) Manpower Mobility Across Cultural Boundaries: Social, Economic and Legal Aspects, The Case of Turkey and West Germany, E.J. Brill, Leiden, Netherlands.

Özden, Ç. (2005) Educated migrants: is there brain waste? in Özden, Ç. and Schiff, M. (eds.) International Migration, Remittances and the Brain Drain, World Bank Publications, Washington, DC, The World Bank and Palgrave MacMillan.

Rea, L. M. and Parker, R. A. (1997) Designing and Conducting Survey Research: A Comprehensive Guide, Second Edition, Jossey-Bass Publishers, San Francisco.

Sjaastad, L. A. (1962) "The Costs and Returns of Human Migration," Journal of Political Economy, 70(5), 80-93.

Stark, O. and Bloom, D. E. (1985) The new economics of labor migration, American Economic Review, Papers and Proceedings, 75(2), 173-78.

Statistical Institute of Turkey (TUIK) (2000) 2000 Census of Population: Social and Economic Characteristics of the Population, TUIK, Ankara.

Statistical Institute of Turkey (TUIK) (2004) Statistical Yearbook of Turkey 2004, TUIK, Ankara.

Tansel, A. and Güngör, N. D. (1997), The educational attainment of Turkey's labour force: A comparison across provinces and over time, METU Studies in Development, 24(4), $531-47$.

Tansel, A. and Güngör, N. D. (2003) 'Brain drain' from Turkey: survey evidence of student non-return, Career Development International, 8(2), 52-69. 
Tomz, M., Wittenberg, J. and King, G. (2001) CLARIFY: Software for Interpreting and Presenting Statistical Results, Version 2.0, June 1, Harvard University, Cambridge, MA. (http://gking.harvard.edu).

UNESCO (2006) Global Education Digest 2006: Comparing Education Statistics Across the World, UNESCO Institute for Statistics, Montreal, Quebec, Canada.

www.uis.unesco.org/TEMPLATE/pdf/ged/2006/GED2006.pdf

Waldorf, B. (1995) Determinants of international return migration intentions, Professional Geographer, 47(2), 125-136.

Zweig, D. and Changgui, C. (1995) China's Brain Drain to the United States: Views of Overseas Chinese Students and Scholars in the 1990s, China Research Monograph, Institute of East Asian Studies, University of California, Berkeley, CA. 
Figure 1: Probability of Return Intentions by Stay Duration

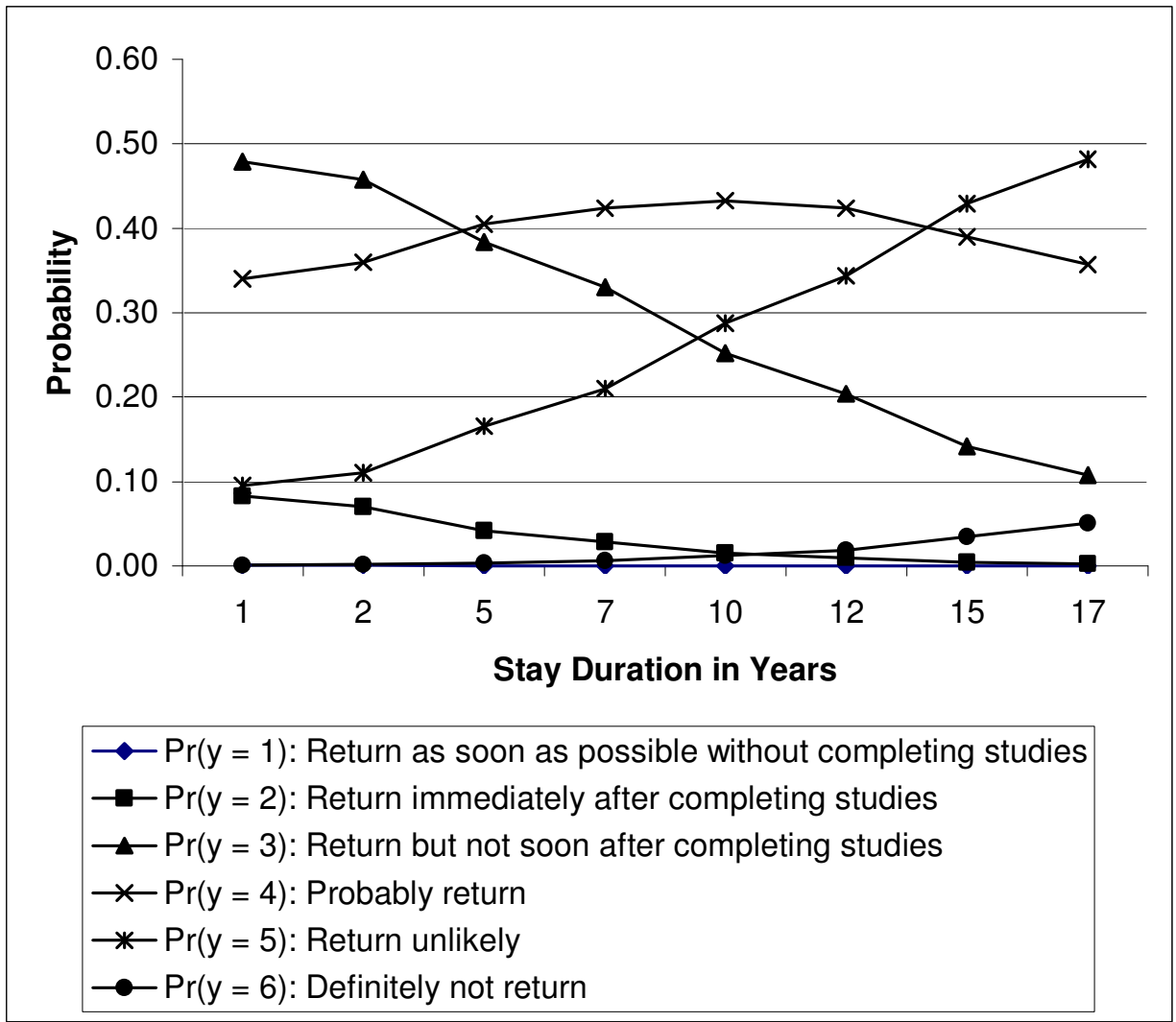


Table 1. Ordered Probit Model of Return Intentions

\begin{tabular}{|c|c|c|c|c|}
\hline Regressors (X) & $\beta$ & z-statistic ${ }^{\mathrm{a}}$ & $\operatorname{MEAN}(\mathrm{X})$ & $\mathrm{SD}(\mathrm{X})$ \\
\hline $\mathrm{X}_{1}$ : Gender (1=female) & 0.124 & $(1.61)$ & 0.39 & 0.49 \\
\hline $\mathrm{X}_{2}:$ Age of respondent in 2001 (years) & 0.036 & $(0.34)$ & 26.96 & 3.67 \\
\hline $\mathrm{X}_{3}$ : Square of age & -0.001 & $(0.60)$ & 740.40 & 207.08 \\
\hline $\mathrm{X}_{4}$ : Initial return intention ( $1=$ unsure $)$ & 0.495 & $(5.66)^{* * *}$ & 0.37 & 0.48 \\
\hline $\mathrm{X}_{5}:$ Initial return intention (1=stay) & 1.434 & $(8.55)^{* * *}$ & 0.09 & 0.29 \\
\hline $\mathrm{X}_{6}$ : Stay duration of respondent (years) & 0.087 & $(4.26)^{* * *}$ & 2.79 & 2.31 \\
\hline $\begin{array}{l}\mathrm{X}_{7} \text { : Family support for settling abroad } \\
\text { (1=somewhat supportive) }\end{array}$ & 0.216 & $(2.55)^{* *}$ & 0.48 & 0.50 \\
\hline $\begin{array}{l}\mathrm{X}_{8} \text { : Family support for settling abroad } \\
\text { (1=definitely supportive) }\end{array}$ & 0.415 & $(3.80)^{* * * *}$ & 0.27 & 0.44 \\
\hline $\mathrm{X}_{9}$ : Social life abroad (1=worse or much worse) & -0.339 & $(4.49)^{* * *}$ & 0.44 & 0.50 \\
\hline $\mathrm{X}_{10}$ : Standard of living abroad ( $1=$ better or much better) & 0.172 & $(1.99)^{* *}$ & 0.69 & 0.46 \\
\hline $\mathrm{X}_{11}$ : Member of Turkish Student Association (1=yes) & -0.167 & $(2.15)^{* *}$ & 0.57 & 0.49 \\
\hline $\mathrm{X}_{12}$ : Divorced or separated (1=yes) & 0.542 & $(2.44)^{* *}$ & 0.02 & 0.15 \\
\hline $\mathrm{X}_{13}$ : Never married (1=yes) & 0.181 & $(1.60)$ & 0.71 & 0.45 \\
\hline $\mathrm{X}_{14}$ : Married to a foreign spouse $(1=\mathrm{yes})$ & 0.545 & (1.64) & 0.02 & 0.14 \\
\hline $\mathrm{X}_{15}$ : Reason for going: learn language ( $\left.1=\mathrm{yes}\right)$ & -0.127 & $(1.47)$ & 0.25 & 0.44 \\
\hline $\mathrm{X}_{16}:$ Reason for going: job requirement in Turkey ( $\left.1=y e s\right)$ & -0.248 & $(3.05)^{* * *}$ & 0.41 & 0.49 \\
\hline $\mathrm{X}_{17}$ : Reason for going: insufficient research facilities (1=yes) & 0.220 & $(2.14)^{* *}$ & 0.45 & 0.50 \\
\hline $\mathrm{X}_{18}$ : Reason for going: prestige of international study (1=yes) & -0.241 & $(2.12)^{* *}$ & 0.72 & 0.45 \\
\hline $\mathrm{X}_{19}$ : Reason for going: lifestyle preference (1=yes) & 0.213 & $(2.06)^{* *}$ & 0.24 & 0.43 \\
\hline $\mathrm{X}_{20}$ : Reason for going: spouse / family consid. $(1=\mathrm{yes})$ & -0.331 & $(1.65)^{*}$ & 0.08 & 0.27 \\
\hline $\begin{array}{l}\mathrm{X}_{21} \text { : Reason for going: get away from political environment } \\
(1=y e s)\end{array}$ & 0.280 & $(2.42)^{* *}$ & 0.25 & 0.44 \\
\hline $\begin{array}{l}\mathrm{X}_{22} \text { : Chose current institution because of job opportunities } \\
(1=y e s)\end{array}$ & 0.290 & $(3.58)^{* * *}$ & 0.26 & 0.44 \\
\hline $\mathrm{X}_{23}$ : Chose current institution to be with spouse (1=yes) & 0.436 & $(2.82)^{* * *}$ & 0.11 & 0.31 \\
\hline $\begin{array}{l}\mathrm{X}_{24} \text { : Previous overseas experience viewed as important } \\
\text { adjustment factor (1=yes) }\end{array}$ & -0.178 & $(2.19)^{* *}$ & 0.34 & 0.47 \\
\hline $\begin{array}{l}\mathrm{X}_{25}: \text { Having Turkish friends/colleagues at institution viewed as } \\
\text { an important adjustment factor (1=yes) }\end{array}$ & -0.128 & $(1.64)$ & 0.57 & 0.50 \\
\hline $\mathrm{X}_{26}$ : Respondent faces unemployment abroad (1=yes) & -0.227 & $(1.33)$ & 0.05 & 0.21 \\
\hline $\mathrm{X}_{27}$ : Respondent plans to work in academia $(A C A D)(1=\mathrm{yes})$ & -0.430 & $(2.51)^{* *}$ & 0.47 & 0.50 \\
\hline $\mathrm{X}_{28}$ : Respondent has compulsory academic service ( $\left.1=\mathrm{yes}\right)$ & -0.705 & $(5.75)^{* * *}$ & 0.18 & 0.38 \\
\hline $\begin{array}{l}\mathrm{X}_{29} \text { : Push factor: lack of research centers and access to recent } \\
\text { advances in Turkey }\end{array}$ & 0.191 & $(2.25)^{* *}$ & 0.59 & 0.49 \\
\hline $\begin{array}{l}\mathrm{X}_{30} \text { : Push factor: less than satisfying cultural / social life in } \\
\text { Turkey }\end{array}$ & -0.061 & & 0.23 & 0.42 \\
\hline $\mathrm{X}_{31}:$ Pull factor: higher level of income in host country & 0.279 & $(3.27)^{* * *}$ & 0.76 & 0.43 \\
\hline $\mathrm{X}_{32}:$ Pull factor: better work environment & -0.104 & $(1.26)$ & 0.68 & 0.47 \\
\hline $\mathrm{X}_{33}$ : Pull factor: greater job availability in specialization & 0.092 & $(1.02)$ & 0.75 & 0.43 \\
\hline $\mathrm{X}_{34}$ : Pull factor: more organized, ordered environment & 0.225 & $(2.50)^{* * *}$ & 0.76 & 0.42 \\
\hline $\mathrm{X}_{35}$ : Pull factor: spouse's preference or job & 0.365 & $(3.53)^{* * *}$ & 0.21 & 0.41 \\
\hline $\mathrm{X}_{36}$ : Pull factor: better educational opportunities for children & -0.116 & $(1.12)$ & 0.19 & 0.39 \\
\hline $\mathrm{X}_{37}$ : Pull factor: incomplete project abroad & -0.087 & $(0.77)$ & 0.30 & 0.46 \\
\hline $\mathrm{X}_{38}:$ Pull factor: other considerations & -0.469 & $(1.53)$ & 0.04 & 0.19 \\
\hline $\mathrm{X}_{39}$ : Last visit to Turkey left negative impression & 0.352 & $(3.99)^{* * *}$ & 0.32 & 0.47 \\
\hline $\mathrm{X}_{40}$ : Last visit to Turkey left positive impression & -0.350 & $(2.91)^{* * *}$ & 0.09 & 0.29 \\
\hline $\mathrm{X}_{41}:$ Effect of Sept. 11 & -0.284 & $(2.79)^{* * *}$ & 0.14 & 0.34 \\
\hline
\end{tabular}

\section{Interactions}

$\mathrm{X}_{42}$ : ACAD x X17 (reason for going abroad: insufficient research facilities) 
$\mathrm{X}_{43}$ : ACAD x X18 (reason for going abroad: prestige of international study)

$\begin{array}{cc}0.349 & (2.13)^{* *} \\ -0.604 & (2.67)^{* * *} \\ 0.370 & (2.03)^{* *} \\ 0.403 & (2.12)^{* *} \\ -0.188 & (1.18) \\ 0.864 & (1.84)^{*}\end{array}$

Notes: Dependent variable $=\mathrm{y}$ (return intentions); $*$ significant at $10 \% ; * *$ significant at $5 \% ; * * *$ significant at $1 \%$; $\beta=$ estimated coefficient; $\operatorname{MEAN}(\mathrm{X})=$ mean value of independent variable; $\mathrm{SD}(\mathrm{X})=$ standard deviation of independent variable; (a) Robust z-statistics in parentheses; Observations $=960 ;$ Log-likelihood $=-1073.44 ; \mathrm{LR} \mathrm{chi}^{2}(48)=583.83$; Maximum Likelihood $\mathrm{R}^{2}=0.491$; McFadden's Adjusted $\mathrm{R}^{2}=0.194$; McKelvey-Zavoina $\mathrm{R}^{2}=0.535$; Akaike Information Criterion $(\mathrm{AIC})=2.347$; Bayesian Information Criterion $(\mathrm{BIC})=-4081.431$. 
Table 2. Marginal Effects of Selected Independent Variables in the Ordered Probit Model of Return Intentions (Change in Probability)

\begin{tabular}{|c|c|c|c|c|c|c|}
\hline \multirow[b]{2}{*}{ Variables } & \multicolumn{6}{|c|}{ Intensity of Return Intentions ${ }^{\mathrm{a}}$} \\
\hline & $\begin{array}{l}y=1 \\
\text { (high) }\end{array}$ & $y=2$ & $y=3$ & $y=4$ & $y=5$ & $\begin{array}{l}y=6 \\
(\text { low })\end{array}$ \\
\hline Female & $\begin{array}{l}-0.0002 \\
(0.00021)\end{array}$ & $\begin{array}{l}-0.0146 \\
(0.00909)\end{array}$ & $\begin{array}{l}-0.0344 \\
(0.02152)\end{array}$ & $\begin{array}{c}0.0234 \\
(0.01428)\end{array}$ & $\begin{array}{c}0.0251 \\
(0.01592)\end{array}$ & $\begin{array}{c}0.0008 \\
(0.00062)\end{array}$ \\
\hline Married to foreign spouse & $\begin{array}{l}-0.0005 \\
(0.00037)\end{array}$ & $\begin{array}{l}-0.0439^{* * * *} \\
(0.01609)\end{array}$ & $\begin{array}{r}-0.1634 \\
(0.10029)\end{array}$ & $\begin{array}{l}0.0615^{* * *} \\
(0.01057)\end{array}$ & $\begin{array}{r}0.1386 \\
(0.10107)\end{array}$ & $\begin{array}{l}0.0078 \\
\mathrm{NR}\end{array}$ \\
\hline $\begin{array}{l}\text { Social Life Abroad: Worse or } \\
\text { Much Worse }\end{array}$ & $\begin{array}{l}0.0007 \\
(0.0005)\end{array}$ & $\begin{array}{l}0.0424^{* * * *} \\
(0.01046)\end{array}$ & $\begin{array}{l}0.0913^{* * *} \\
(0.02038)\end{array}$ & $\begin{array}{l}-0.0661^{* * *} \\
(0.01568)\end{array}$ & $\begin{array}{c}-0.0662^{* * *} \\
(0.0148)\end{array}$ & $\begin{array}{l}-0.0021^{* * *} \\
(0.00089)\end{array}$ \\
\hline $\begin{array}{l}\text { Standard of Living Abroad: } \\
\text { Better or Much Better }\end{array}$ & $\begin{array}{c}-0.0004 \\
\text { NR }\end{array}$ & $\begin{array}{l}-0.0219^{*} \\
(0.01197)\end{array}$ & $\begin{array}{l}-0.0463^{* *} \\
(0.02256)\end{array}$ & $\begin{array}{l}0.0344^{*} \\
(0.01789)\end{array}$ & $\begin{array}{l}0.0332^{* *} \\
(0.01636)\end{array}$ & $\begin{array}{l}0.0015^{*} \\
(0.0009)\end{array}$ \\
\hline $\begin{array}{l}\text { Turkish Student Association } \\
\text { membership }\end{array}$ & $\begin{array}{l}0.00034 \\
(0.00026)\end{array}$ & $\begin{array}{l}0.0198^{* *} \\
(0.00903)\end{array}$ & $\begin{array}{l}0.0462^{* *} \\
(0.02193)\end{array}$ & $\begin{array}{l}-0.0315^{* *} \\
(0.01447)\end{array}$ & $\begin{array}{l}-0.0337^{* *} \\
(0.01609)\end{array}$ & $\begin{array}{c}-0.0004 \\
\text { NR }\end{array}$ \\
\hline \multicolumn{7}{|l|}{ Reasons for going abroad: } \\
\hline Job requirement in Turkey & $\begin{array}{c}0.0006 \\
(0.00041)\end{array}$ & $\begin{array}{c}0.0311^{* * *} \\
(0.01111)\end{array}$ & $\begin{array}{l}0.0672^{* * *} \\
(0.02157)\end{array}$ & $\begin{array}{l}-0.0487^{* * * *} \\
(0.01652)\end{array}$ & $\begin{array}{l}-0.0485^{* * *} \\
(0.01585)\end{array}$ & $\begin{array}{l}-0.0015^{* *} \\
(0.00075)\end{array}$ \\
\hline Lifestyle preference & $\begin{array}{l}-0.0004 \\
(0.00027)\end{array}$ & $\begin{array}{l}-0.0238^{* *} \\
(0.01079)\end{array}$ & $\begin{array}{l}-0.0606^{* *} \\
(0.03025)\end{array}$ & $\begin{array}{l}0.0380^{* *} \\
(0.01715)\end{array}$ & $\begin{array}{l}0.0451^{*} \\
(0.02317)\end{array}$ & $\begin{array}{c}0.0017 \\
(0.00105)\end{array}$ \\
\hline To be with spouse / family ${ }^{b}$ & $\begin{array}{c}0.0039 \\
(0.00296)\end{array}$ & $\begin{array}{l}0.1077^{* * *} \\
(0.03632)\end{array}$ & $\begin{array}{l}0.1190^{* * *} \\
(0.02144)\end{array}$ & $\begin{array}{l}-0.1399^{* * *} \\
(0.03895)\end{array}$ & $\begin{array}{l}-0.0886^{* * *} \\
(0.01781)\end{array}$ & $\begin{array}{l}-0.0022^{* * *} \\
(0.00083)\end{array}$ \\
\hline $\begin{array}{l}\text { y from political } \\
\text { ment }^{b}\end{array}$ & $\begin{array}{l}-0.0008 \\
(0.00056)\end{array}$ & $\begin{array}{l}-0.0460^{* * * *} \\
(0.00935)\end{array}$ & $\begin{array}{l}-0.1308^{* * *} \\
(0.02897)\end{array}$ & $\begin{array}{l}0.0711^{* * *} \\
(0.01361)\end{array}$ & $\begin{array}{l}0.1020^{* * * *} \\
(0.02442)\end{array}$ & $\begin{array}{l}0.0046^{* * * *} \\
(0.00193)\end{array}$ \\
\hline $\begin{array}{l}\text { Reason for choosing current } \\
\text { institution: job opportunities }\end{array}$ & $\begin{array}{l}-0.0005 \\
(0.00034)\end{array}$ & $\begin{array}{l}-0.0316^{* * *} \\
(0.00855)\end{array}$ & $\begin{array}{l}-0.0829^{* * *} \\
(0.02397)\end{array}$ & $\begin{array}{l}0.0504^{* * *} \\
(0.01324)\end{array}$ & $\begin{array}{l}0.0623^{* * *} \\
(0.01876)\end{array}$ & $\begin{array}{l}0.0024^{* *} \\
(0.00111)\end{array}$ \\
\hline $\begin{array}{l}\text { Adjustment facto } \\
\text { experience }\end{array}$ & $\begin{array}{c}0.0004 \\
(0.00031)\end{array}$ & $\begin{array}{l}0.0224^{* *} \\
(0.01086)\end{array}$ & $\begin{array}{l}0.048^{* *} \\
(0.02143)\end{array}$ & $\begin{array}{l}-0.0353^{* *} \\
(0.01662)\end{array}$ & $\begin{array}{l}-0.0345^{* *} \\
(0.01535)\end{array}$ & $\begin{array}{l}-0.0011^{*} \\
(0.00061)\end{array}$ \\
\hline $\begin{array}{l}\text { Adjustment factor: Turkish } \\
\text { friends at institution }\end{array}$ & $\begin{array}{c}0.0002 \\
(0.00023)\end{array}$ & $\begin{array}{c}0.0152 \\
(0.00938)\end{array}$ & $\begin{array}{c}0.0353 \\
(0.02169)\end{array}$ & $\begin{array}{l}-0.0242^{*} \\
(0.0147)\end{array}$ & $\begin{array}{l}-0.0257 \\
(0.01599)\end{array}$ & $\begin{array}{l}-0.0009 \\
(0.00062)\end{array}$ \\
\hline $\begin{array}{l}\text { Difficulties faced while abroad: } \\
\text { unemployment }\end{array}$ & $\begin{array}{l}0.0007 \\
(0.00084)\end{array}$ & $\begin{array}{c}0.0319 \\
(0.02785)\end{array}$ & $\begin{array}{c}0.0573 \\
(0.03853)\end{array}$ & $\begin{array}{l}-0.0485 \\
(0.03924)\end{array}$ & $\begin{array}{l}-0.0404 \\
(0.0272)\end{array}$ & $\begin{array}{l}-0.0011 \\
(0.00075)\end{array}$ \\
\hline $\begin{array}{l}\text { Respondent plans to work in } \\
\text { academia }^{\text {b }}\end{array}$ & $\begin{array}{c}0.0004 \\
(0.00034)\end{array}$ & $\begin{array}{l}0.0205^{* *} \\
(0.00963)\end{array}$ & $\begin{array}{l}0.0492^{* *} \\
(0.02182)\end{array}$ & $\begin{array}{l}-0.0325^{* *} \\
(0.01480)\end{array}$ & $\begin{array}{l}-0.0362^{* *} \\
(0.01627)\end{array}$ & $\begin{array}{l}-0.0013^{*} \\
(0.00079)\end{array}$ \\
\hline $\begin{array}{l}\text { Respondent has compulsory } \\
\text { academic service }\end{array}$ & $\begin{array}{l}0.0035^{*} \\
(0.00195)\end{array}$ & $\begin{array}{l}0.1177^{* * *} \\
(0.02773)\end{array}$ & $\begin{array}{l}0.1472^{* * *} \\
(0.01907)\end{array}$ & $\begin{array}{l}-0.1573^{* * *} \\
(0.03078)\end{array}$ & $\begin{array}{l}-0.1085^{* * *} \\
(0.01453)\end{array}$ & $\begin{array}{c}-0.0027 \\
\text { NR }\end{array}$ \\
\hline $\begin{array}{l}\text { Push factor: lack of research } \\
\text { centers and access to recent } \\
\text { advances in Turkey }\end{array}$ & $\begin{array}{l}-0.0004 \\
(0.00034)\end{array}$ & $\begin{array}{c}-0.0237^{* *} \\
(0.01113)\end{array}$ & $\begin{array}{l}-0.0519^{* *} \\
(0.02279)\end{array}$ & $\begin{array}{l}0.0374^{* *} \\
(0.01717)\end{array}$ & $\begin{array}{l}0.0375^{* *} \\
(0.01644)\end{array}$ & $\begin{array}{c}0.0012 \\
\text { NR }\end{array}$ \\
\hline
\end{tabular}




\begin{tabular}{lcccccc}
$\begin{array}{l}\text { Pull factor: higher level of } \\
\text { income in host country }\end{array}$ & -0.0007 & $-0.0378^{* * *}$ & $-0.0723^{* * *}$ & $0.0578^{* * *}$ & $0.0514^{* * *}$ & 0.0015 \\
& $\mathrm{NR}$ & $(0.01292)$ & $(0.02119)$ & $(0.01902)$ & $(0.01479)$ & $\mathrm{NR}$ \\
$\begin{array}{l}\text { Pull factor: greater job } \\
\text { availability in specialization }\end{array}$ & -0.0002 & -0.0114 & -0.0248 & 0.0181 & 0.0178 & 0.0006 \\
& $(0.00024)$ & $(0.01163)$ & $(0.02399)$ & $(0.0182)$ & $(0.01711)$ & $(0.00055)$ \\
& & & & & & \\
$\begin{array}{l}\text { Pull factor: more organized, } \\
\text { ordered environment }\end{array}$ & -0.0006 & $-0.0298^{* *}$ & $-0.0592^{* * *}$ & $0.0461^{* *}$ & $0.0422^{* * *}$ & 0.0012 \\
& $\mathrm{NR}$ & $(0.01298)$ & $(0.02274)$ & $(0.01976)$ & $(0.01577)$ & $\mathrm{NR}$ \\
$\begin{array}{l}\text { Pull factor: spouse's preference } \\
\text { or job }\end{array}$ & -0.0006 & $-0.0378^{* * *}$ & $-0.1057^{* * *}$ & $0.0595^{* * *}$ & $0.0813^{* * *}$ & $0.0033^{* *}$ \\
& $(0.00038)$ & $(0.00967)$ & $(0.03134)$ & $(0.01474)$ & $(0.02551)$ & $(0.00159)$ \\
$\begin{array}{l}\text { Last visit to Turkey left } \\
\text { negative impression }\end{array}$ & -0.0006 & $-0.0387^{* * *}$ & $-0.1000^{* * *}$ & $0.0612^{* * *}$ & $0.0753^{* * *}$ & 0.0029 \\
& $(0.00039)$ & $(0.00925)$ & $(0.02629)$ & $(0.01455)$ & $(0.02041)$ & $\mathrm{NR}$ \\
$\begin{array}{l}\text { Last visit to Turkey left } \\
\text { positive impression }\end{array}$ & 0.0012 & $0.0521^{* *}$ & $0.0843^{* * *}$ & $-0.0766^{* * *}$ & $-0.0595^{* * *}$ & $-0.0016^{* *}$ \\
& $(0.00089)$ & $(0.02162)$ & $(0.02477)$ & $(0.02917)$ & $(0.01726)$ & $(0.00065)$ \\
\hline & & & & & & \\
\hline
\end{tabular}

Notes: The table gives the change in the probability associated with each of the return intentions categories for the dummy variables listed when the value of the dummy variable changes from 0 to 1 . The figures below in parentheses are the standard errors of the marginal effects.

* significant at 10\%; ** significant at 5\%; *** significant at 1\%; NR indicates that the standard error could not be calculated and is therefore not reported.

${ }^{a}$ See the table in the methodology section for further details of the categories of the return intentions variable.

${ }^{\mathrm{b}}$ Indicates variables with interactions whose marginal effects and standard errors are calculated with the software Clarify (King, Tomz and Wittenberg, 2000; Tomz, Wittenberg and King, 2001). 
Relative importance of selected factors on definitely returning (probability of $\mathrm{y}=1$ or $\mathrm{y}=2$ )

\section{Factor (\% of respondents)}

Marginal

Impact

Having compulsory academic service requirement (17.8\%)

0.1212

0.1116

Choosing same location as spouse to study abroad ( $7.9 \%)$

0.1067

Respondent's initial intention is to return (54.1\%)

0.0533

Last visit to Turkey left a positive impression ( $9.5 \%)$

0.0431

Effect of September 11, 2001 attacks in US (13.7\%)

0.0409

Inability to find a job abroad ( $4.7 \%)$

0.0326

Relative importance of selected factors on definitely not returning (probability of $\mathrm{y}=5$ or $\mathrm{y}=6$ )

\section{Factor (\% of respondents)}

Marginal

Being married to a foreign spouse ( $2.0 \%)$

Impact

Left Turkey to get away from political environment (25.3\%)

0.1464

0.1066

Family is definitely supportive in the decision to settle abroad (26.8\%)

0.0851

Last visit to Turkey left a negative impression (31.7\%)

0.0782

Higher level of income is chosen as an important pull factor (76.4\%)

0.0529

Lifestyle preference is given as an important initial reason for going abroad (24.4\%)

0.0468

A more organized and ordered environment abroad is an important pull factor (76.5\%)

0.0457

Notes: $\mathrm{y}=1$ corresponds to "immediately return without completing studies" and $\mathrm{y}=2$ corresponds to the "immediately return after completing studies" categories; $y=5$ corresponds to the "return unlikely" and $y=6$ corresponds to the "definitely not return" categories.

Source: Authors' calculations. 


\section{Appendix A}

\section{A.1 Survey Methodology}

The Internet survey targeted students at the undergraduate or graduate level studying at higher education institutions outside Turkey. The initial part of the sampling strategy involved compiling a list of the names and e-mail addresses of potential participants that would serve as the sampling frame. The collection of potential participant names and contact information depended to a great extent on the existence and accessibility of student and personnel directories at institutions of higher learning and research centers, the existence of accessible and up-to-date alumni directories of Turkish universities, and the help of various Turkish associations abroad. Unfortunately, the reliance on internet search procedures in the construction of a list of potential participants inevitably set limitations on who could be reached. For example, individuals who were not members of any overseas Turkish associations, nor listed in any directories, and without e-mail address information (especially older participants) cannot be said to be adequately represented. Another limitation is that the search for survey participants concentrated on universities and associations in North America and England; time considerations did not permit expanding the search to other important destination countries, such as Germany. The construction of a list of candidates, given the limited time frame for conducting the survey, could not be expected to be exhaustive and uncover each possible survey candidate.

An e-mail cover letter was sent to potential participants discovered through the search process described above. The cover letter explained the purpose of the study and contained a link to the web address of the survey page. Survey candidates were invited to participate in the study and to forward the cover e-mail letter to colleagues and friends who they believed would fit the targeted survey population. Asking the initial group of contacts to assist in reaching other potential participants who are in the targeted populations is a nonprobability 
sampling method known as "snowball" or "referral" sampling (Atkinson and Flint, 2001; Rea and Parker, 1997). This sampling strategy is used when the size and distribution of the populations are not known with certainty, and the probability that a given respondent will be picked as part of the sample is also unknown.

Referral sampling is a fast and efficient, but potentially biased, means of reaching the targeted populations, which introduces the possibility that non-participants may differ systematically from participants in terms of their characteristics and in their return intentions. For this reason, the survey results cannot be used to generalize to the full targeted populations. Nevertheless, the combination of internet search and "snowball" sampling resulted in a total of 1170 responses from Turkish students studying abroad. After eliminating responses from non-target populations and incomplete answers ${ }^{12}$, the number of valid responses totaled 1103 . The sample sizes of the econometric models are smaller. This is due to the fact that response rates vary for some of the questions included as regressors in the estimated models.

\section{A.2 Choice of Estimation Methodology}

The ordered response model makes the assumption that the explanatory variables of the model will have the same impact across each of the categories of the dependent variable, which is known as the "parallel regression assumption" (Long and Freese, 2001). It could well be that the coefficients of some or all of the explanatory variables are significantly different across each categorical choice, in which case alternative models must be considered,

\footnotetext{
12 Non-target populations included respondents from the Turkish Republic of Northern Cyprus and secondgeneration citizens of Turkish origin. Incomplete responses were eliminated on the basis of the extent of incompleteness (e.g. if a majority of the questions were left unanswered or if important portions of the survey were not filled out).
} 
such as the multinomial logit model or generalized ordered logit / probit models. In the generalized ordered models, a separate parameter vector is estimated for each of the $J$

categories (e.g., $\beta^{1}, \beta^{2}, \ldots, \beta^{J}$ ). We have tested the parallel regression assumption with an approximate LR test and a Wald test (Long and Freese, 2001) and rejected it.

Although the parallel regression assumption is violated, we base our results on the ordered probit model. Alternative estimation methodologies were employed, but we found that their shortcomings outweighed the advantages they offered. The drawback of using the multinomial logit model, for example, is that it does not preserve the inherent ordering of the return intention categories and therefore does not incorporate this information when estimating the coefficients of the explanatory variables. This results in a loss in the efficiency of the estimators (Long, 1997). While the generalized ordered logit model provides an alternative model that does preserve the ordering (e.g., it is a restricted version of the multinomial logit model), it is very sensitive to low frequency counts (e.g., small cell sizes). Thus, it is often necessary to combine the dependent variable categories that have low frequencies with adjacent categories in order for the estimation procedure to work. However, combining categories may also lead to a loss in information, especially if the underlying latent variable is multi-leveled or continuous. For example, while the "definitely not return" category has relatively few observations, it expresses a much more intense feeling about returning than the "unlikely to return" category, which is an important distinction within the context of the current study. As a result, we have chosen to present the results from the ordered probit model. A larger sample size and fewer explanatory variables would have made the use of generalized models more feasible.

\section{A.3 Model Selection based on Estimation of Exploratory Ordered Probit Models}

In part A.2, the ordered probit model was chosen as an appropriate estimation method based on the characteristics of the dependent variable. In this section, we describe the model 
selection procedures used to determine the set of regressors to keep in the final estimation model. There are several things to note. One is that the set of possible regressors do not have the same number of valid points (cross-sections) because of missing responses. Including some of these regressors will come at the cost of reducing the sample size and thus the precision of the estimated parameters. On the other hand, excluding key variables will also compromise the fit of the estimated model.

An initial criterion for reducing the number of regressors is to exclude variables with a large number of missing responses that are not significantly associated with the dependent variable, based on the chi-square test of independence. Migration theory also serves to provide a guideline for keeping or excluding variables from the initial model.

After determining the initial set of explanatory variables the next stage in model selection involves adopting an appropriate strategy for choosing the best possible model—one that fits the data well and is relatively easy to interpret. The model may be complicated by non-linearities and interactions among the regressors. One approach to take would be to start from a saturated model - a model that incorporates all possible variables, interactions and higher-order terms - and to use a backward elimination procedure. At each step, terms that are not statistically significant individually and that also do not contribute significantly to the fit of the model are eliminated. The elimination procedure continues until further model reduction involves a significant deterioration in model fit. The advantage of this approach is that all of the reduced or pared down models are nested in the previous models so that one could use testing procedures, such as the likelihood ratio (LR) test, that are suitable for testing nested non-linear models. Otherwise, measures of fit based on information criteria must be used to compare non-nested models or models with different sample sizes.

One of the difficulties faced is that the response rates vary considerably across different sets of questions in the survey study. For example, there is a lower response rate for questions 
appearing at the end of the survey than for those appearing at the beginning. This means that starting from a saturated model with all possible sets of regressors, even with the initial reduction in the variable set, leads to a significant reduction in the sample size. Another approach that can be used is that of forward selection where the explanatory variables are added sequentially to the model. The criteria for adding a variable is based on whether the new variable significantly improves the fit of the model. With this strategy, the explanatory variables that have the greatest significant bivariate association with the dependent variable are used in the initial regression; then, more complicated models are gradually built up from this preliminary model. The disadvantage of this approach is that the final model may be sensitive to the initial set of regressors and to the order in which the remaining regressors are added. 